NBER WORKING PAPER SERIES

\title{
ARE ESTIMATED TAX ELASTICITIES REALLY JUST \\ TAX EVASION ELASTICITIES? \\ THE CASE OF CHARITABLE CONTRIBUTIONS
}

Joel Slemrod

Working Paper No. 2733

NATIONAL BUREAU OF ECONOMIC RESEARCH

1050 Massachusetts Avenue

Cambridge, MA 02138

October 1988

This research was supported by a contract with the Office of Tax Analysis, U.S. Department of the Treasury. National Science Foundation Grant No. SES 86-10021 also provided financial support. Len Burman, Daphne Kenyon, and Mike Udell have provided valuable assistance. Helpful comments on an earlier draft were received from Jerry Auten, Len Burman, and Jerry Schiff. The views expressed here do not necessarily represent the views of the Department of the Treasury. This research is part of NBER's research program in Taxation. Any opinions expressed are those of the author not those of the National Bureau of Economic Research. 
NBER Working Paper $\$ 2733$

October 1988

\title{
ARE ESTIMATED TAX ELASTICITIES REALLY JUST \\ TAX EVASION ELASTICITIES? \\ THE CASE OF CHARITABLE CONTRIBUTIONS
}

\begin{abstract}
Tax return data, which has been a principal source for econometric investigations of the behavioral response to tax policy, is subject to misreporting that may bias estimates of tax responsiveness. The misreporting arises because understatement of taxable income may itself be a function of an individual's marginal tax rate, it being the return to a dollar of understated taxable income. To the extent that misreporting of income and deductions is a function of the same factors that determine the behavior under study, estimated relationships based on reported data will reveal a composite of the tax (and income) responsiveness of the actual behavior and of the misreporting of the behavior.

This paper used data from tax returns that have been subject to intensive audits to confront the quantitative importance of misreporting for the estimated tax responsiveness of charitable contributions. This has been the subject of numerous empirical studies using tax return data which use a common empirical framework. It concludes that the tax responsiveness of charitable giving that has been detected using tax return data cannot be ascribed to the tax responsiveness of overstating actual giving. In fact. overstatement is apparantly less price responsive than actual giving, implying that the responsiveness of actual giving is higher than is suggested by studyling reported contributions.
\end{abstract}

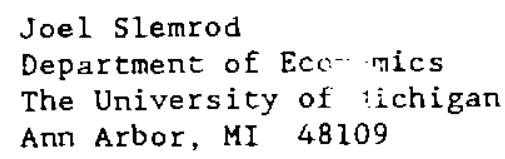




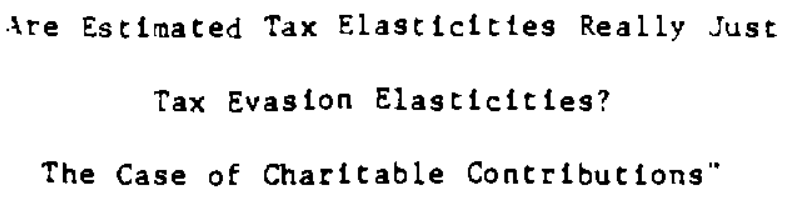

${ }^{1}$ Clotfelter and Steuerle (1981), after noting the relative advantage of tax return data over survey data (including the belief that charitable contributlons are reported more accurately on tax returns, primar1ly because the taxpayer is required to keep some records for tax purposes), note:

"Contributions, of course, may be overstated by taxpayers. Furthermore, the incentive to overstate contributions is proportional to the marginal tax rate, making it virtually impossible to separate the true incentive effect on contributions from any systematic overstatement effect." (p. 424) 
Issue to investigate in this context because it has been the subject of numerous empirical studies using tax return data ${ }^{2}$ which use a common empirical

framework. In addition, evidence to be discussed below indicates that overstatement of charitable contributions is a quantitatively significant phenomenon.

\section{Motivation}

Most empirical studies of charttable contributions assume that the underlying demand may be expressed as a constant-elasticlty function of the aftertax price of making a contribution (P), incore ( $Y$ ), and other factors. SubsumIng factors other than price and income into a constant term, chis relationship can be writcen as

$$
c_{R}=a_{R} P^{B_{R}}{ }^{Y_{R}}
$$

where the subscripts $R$ are reant to stand for the amount reported on unaudited tax returns. The after-tax price of making a one dollar contribution is equal to one for taxpayers who do not itemize deductions, and is equal to $1-t$, where

t is the marglnal tax zate, for taxpayers who do ttemize deductions.

Now suppose that reported contributions are the sum of two components, actual contributions and overstated contributions, so that $C_{R}=C_{A}+C_{E}$, where $C_{A}$ ts actual contributions and $C_{E}$ is overstated contributions. Fut ther suppose that overgtated contributions are also a constant elasticity function of $Y$ and P, so that

$$
C_{E}=a_{E} P^{B_{E}} Y^{Y_{E}}
$$

\footnotetext{
${ }^{2}$ An excellent survey of this itterature is contalned in clotfelter and Steuerle (1981).
} 
Here, $P$ should be interpeted as one rinus the return to successfully overstating charitable deductions by one dollat, also equal to $1-t$. Combining (1) and (2), we see that

$$
c_{A}=C_{R}-c_{E}=a_{R} q^{3} R Y^{Y} R-a_{E} P^{B_{E}}{ }_{Y}^{Y} E \text {. }
$$

The relationship between the price elasticity of reported charitable contributions, equal to $B_{R}$, and the price elasticity of actual contributions, ${ }^{3} A$, can be calculated from (3) to be

$$
B_{A}=\frac{B_{R} C_{R}-\beta_{E} C_{E}}{C_{A}} .
$$

The ratio of the price elasticity of actual contributions to the price elasticity of reported contributions can also be written, using the fact that $C_{R}=C_{A}+C_{E}$, as

$$
\frac{\beta_{A}}{B_{R}}=1+\left(\frac{{ }_{B}-B_{E}}{\beta_{R}}\right)\left(\frac{C_{E}}{C_{A}}\right)
$$

Expression ( 5 ) indicates that the absolute value of $B_{A}$ will be less than $\left|B_{R}\right|$ as long as $\left|B_{E}\right|>\left|B_{R}\right|$. Here and below we assume that $\beta_{E}$ and $B_{R}$ are less than zero. The degree by which ${ }_{R}$ w111 rotstepresent $B_{A}$ depends on both the Afvergence of $B_{E}$ and $B_{R}$ and the relative magnitude of overstated contributions compared to actual contributions.

Ignoring the distinction between reported and actual charitable contributions may also bias estimates of the responsiveness of reported contributions, which are important in their own right because it 1 s the response of reported and not actual contributions that determines the revenue implications of changes 
In the tax treatment of charitable contributions. ${ }^{3}$ For example, one criterion for judging the approprlateness of allowing a deduction for charitable contributions is whether the increase in contributions is greater than the loss in government revenues from the polfcy. The standard reasoning that ignores misreporting finds that this occurs if the price elasticity of contributions (assumed to be constant) is greater than one in absolute value, or if $|B|>1$. When the possibility of overreporting is considered, the condition becomes

$$
\left|B_{R}\right|>1+s\left|\beta_{E}\right| \quad s=\frac{C_{E}}{(1-t) C_{R}} .
$$

Accotding to (6), if there is any price responsiveness of overstatement, a value of $\left|B_{R}\right|$ higher than one is required for the increase in contributions to exceed the revenue cost. Furthermore, the estimate of $\beta_{R}$ remains a critical factor in the determination of the effectiveness of the deduction. If estimates of $\beta_{R}$ based on tax return data are too high, then this criterton of effectiveness may be accepted when it in fact does not hold.

The goal of what follows is to assess the quantitative significance of recognizing the difference between reported and actial contributions. A theoretical framework for this investigation is presented next.

\section{A Simple Model of Individual Behavior}

Assume that the representative individual derives utility from two goods, a composite good and actial charitable contributions $\left(C_{A}\right)$, which must be financed frow an exogenous level of incore, $Y$. The individual must nake three decisions--what level of $C_{A}$ to choose, what level of contributions to report

\footnotetext{
${ }^{3}$ This statement, and the condition derived below, do not consider the revenue obtalned from fines and assessments, which is small relative to cotal revenue collected.
} 
to the tax authorities $\left(C_{R}\right)$, and what level of non-chartty income understatement to attempt $(G)$. There is a probability p that the individual's tax return w11l be audited, In which case all evasion is uncovered. Detected evasion is subject to a fine, denoted $F$, which depends on the amount of 1ncore understatement. The probability of detection is presumed to be positively related to the amount of charity evasion that is attempted and on the amount of non-chatity evasion. The precise relationship between evasion and $p$ may involve $C_{A}$, for reasons discussed below, and other factors, represented by 2 . This maxlmization problem can be written as

$$
\begin{aligned}
& \underset{C_{R}, G, C_{A}}{\operatorname{Maximize}}\left[1-P\left(C_{R}, C_{A}, G, Z\right)\right] \cup\left[Y-t\left(Y-G-C_{R}\right)-C_{A}, C_{A}\right]+ \\
& \qquad\left(C_{R}, C_{A}, G, Z\right) \cup\left[Y-t\left(Y-C_{A}\right)-C_{A}-F\left(G+C_{R}-C_{A}\right), C_{A}\right] \\
& \text { subject to } C_{A}, C_{R}>0 .
\end{aligned}
$$

Expression (7) presumes a proportional incore tax system where actual charitable contributions are fully deductible, and recognizes no difference between real income and taxable income, except that contributions are a deductible item. Assuming that the inequality constraints are not binding, the first-order conditions for $C_{R}, G$, and $C_{A}$ are, respectively,

$$
\begin{aligned}
& (1-p) t U_{1}^{n}-p F^{\prime} U_{1}^{d}-p_{R}^{\prime}\left(U^{n}-U^{d}\right)=0, \\
& (1-p) t U_{1}^{n}-p F^{\prime} v_{1}^{d}-p_{G}^{\prime}\left(J^{n}-U^{d}\right)=0
\end{aligned}
$$

and

$$
(1-p)\left[-U_{1}^{n}(1-t)+U_{2}^{n}\right]+p\left[-U_{1}^{d}(1-t)+U_{2}^{d}\right]-p_{A}^{i}\left(U^{n}-U^{d}\right)=0
$$

where superscripts $n$ and $d$ refer to utility (marginal or total) evaluated at the levels appropriate to the state of the world in which the taxpayer is not 
audited and audited, respectively, and $P_{R}^{\prime}, P_{G}^{\prime}$, and $P_{A}^{\prime}$ are $\partial p / \partial C_{R}, \partial p / \partial G$, and $\partial p / \partial C_{A}$, respectively. $F^{\prime}$ is $\partial F / \partial\left(G+C_{R}-C_{A}\right)$.

Note that the first-order condition for $C_{R}$ is no different from the one that would apply if the problem was posed as a choice of $C_{E}$ instead of $C_{R}$; that is, given $C_{A}$ the cholce of $C_{R}$ is equivalent to choosing $C_{E}$. Expression (8) Indicates that a lower probability of detection and a higher marginal tax rate $^{4}$ make the expected payoff from charlty overstatement higher. A higher value of $U^{n}-U^{d}$, the utility cost of detection, lowers the expected payof from charity overgtatement, ceteris paribus. The utility cost of detection depends positively on the total amount of evasion attempted, the fine rate, and the degree of risk aversion. A higher value of $\left|P_{R}^{\prime}\right|$, which may depend on actual contributions and non-charlty evaston, also reduces the atcractiveness of charity overstaterent.

The first-order condition for non-chartty evasion is of similar fora to the condition for charity reporting (overstatement), except that $P_{R}^{\prime}$ is replaced by $P_{G}^{\prime}$. This implies that the mix of evasion attempted will depend on the relative impact on the likelthood of detection of charity overstatement versus nonchartity evaston. This will vary depending on the opportunities for evasion avallable to the Individual and, in a more general rodel, the resources expended to camouflage the evasion so as to escape detection.

Note that, although total evasion will never be negative, either $\mathrm{C}_{E}$ or $G$ may be negative. To see this, consider a taxpayer who has an excellent

\footnotetext{
${ }^{4}$ Although note that if the penalty for evasion is a fixed percentage of tax liability understated, as is often the case in the U.S., a change in the marginal tax rate affects the return to successful evasion proportionally to the cost of unsuccessful evasion. As Y1tzhaki (1974) has argued, this implies that when $p$ is $f$ ixed a change in $t$ causes no sibstitution effect. tn this model where $p$ depends on $C_{R}$ and $G$, a change in $t$ would in general change the form of (8) and (9).
} 
opportunity ( $\left|p_{G}\right|$ is low) to do a large amount of non-charity evasion. Thus the utility cost of detection, $U^{n}-U^{d}$, is high. As long as $P^{\prime} R^{\text {is }}$ positive, it may be optimal to understate charttable contributions so as to reduce the probability of an audit that would uncover the non-charity evasion. 5

Now consider the first-order condition for actual contributions, expression (10). Ignoring the final term on the left-hand side, this is a slightly modified version of the standard first-order condition for desired charitable contributions, stating that the ratio of expected marginal utility from the composite good and charitable contributions should equal their relative price, 1-t. The extent that the amount of actual contibutions influences the probability of detection ( $P_{A}^{\prime}$ ) also enters the first-order condition. This may be important in the case of overvaluation of noncash contributions, where the existence of some actual contributions may faclitiate the act of overstateaent $\left(p_{\mathrm{A}}<0\right)$. Thus, an individual who is inelined to evade taxes by overstating charitable deductions may also do more actual contributions than otherwise. 6

\section{Description of Data}

The data ised in this study were collected by the Internal Revenue Service as part of their Taxpayer Compliance Measurement Program (TCMP). The data contalns Information about the tax return filed and the result of an intensive audit of a stratified ${ }^{7}$ random sample of the $x$ spaying population in 1982 . Eor

5t is assumed that, upon audt, the understatement of charttable contributions will be revealed and rectified.

${ }^{6}$ P1tt (1981) has studled this phenomenon in connection with smuggling, where legal imports faclittate underinvolcing, allowing other imports to escape input tariffs.

7 Returns are candomly selected within each of twelve examination classes. 
each line on the tax return, the data contains the Eigure reported by the taxpayer and the amount deemed by the auditor to be "correct." 8

According to the IRS Manual, an auditor ray adjust the amount reported Eor the deduction for charitable contributions Eor any of twenty-six different reasons. 9 For example, the auditor may judge that some or all of the reported contributions were not actually made, that some donated property was overvalued by the contributor, or that the recipient was not a qualified charitable organization. It is also possible that the audicor may disallow the deduction for some contributions that were actually made because of inadequate documentation. Because of this possibility and more generally because the auditing process is an imperfect one, 10 there is no presumption that the audicor-adjusted figure for charicable contributions represents the actual value of contributions. Nor should it be assumed that the difference between reported contributions and auditor-adjusted contributions represents willeul tax evasion.

Table 1 presents some sumary statistics from the 19B2 TCMP about reported charitable contributions and auditor-adjusted charitable contributions by 1ncome class. In addition, the ratio of the difference between reported and auditor-adjusted contributions to reported amounts is given, both including and not including upward adjustments to the reported amount. Table 1 indicates that total downward adjustments in reported charitable contributions amounted

${ }^{8}$ The micro-unit data from the 1969 TCMP survey has been used by Clotfelter (1983) in a study of the effect of tax rates on the extent of tax evasion, and TCMP data aggregated by $z$ ip code has been used by Witte and Woodward (1985) and Dubin and Wilde (1986) to study the determinants of taxpayer noncorpliance.

'Information about the reason given by the auditor for adjusting a given reported contribution was not avallable for this study.

10 Alexander and Feinstein (1986) control for differential auditor effectiveness in their study of the determinants of tax evasion. 
to $8.9 \%$ of reported contributions. This is offset by upward adjustments of $1.7 \%$ of reported contributions, so that the net adjustment is $7.2 \%$ downward. The other important aspect of Table 1 is that the relative extent of downward adjustment is, for the most part, sharply decreasing with income. The downward adjustments amount to more than $10 \%$ of reported contributions for taxpayers with incore between $\$ 20,000$ and $\$ 50,000$, between $4 \%$ and $10 \%$ for taxpayers with Income between $\$ 50,000$ and $\$ 1,000,000$ and is only $1.1 \%$ for taxpayers with Incore over $\$ 1,000,000$. Ignoting variations in the price of giving, this finding suggests that the income elasticity of reported contributions understates the incore elasticity of auditor-adjusted contributions. Because the price of giving tends to decrease with higher income, the data suggests that the sum of the income elasticity and the (absolute value) of the price elasticity is higher for autitor-adjusted contributions than for reported contributions.

5. Emplrical Models and Results

As a first step I attempt to replicate the standard log IInear ordinary least-squares regression analysis of charitable contributions using reported data. Because the focus of this study is the empirical 1mportance of nonconpliance on standard estimation results, $\tau$ will not discuss in detail alternatives to the standard econometic approach of which Clotfelter and Steuerle ( 1981$)$ is an excellent example. 11 Following Clotfelter and Steuerle, the dependent varfable is $\ln (C+10)$. The first iadependent variablie fs the natural logarithm of the after-tax price of one dollar of contribution (LNP), equal to one minus the marginal federal

\footnotetext{
${ }^{11}$ See Reece and zieschang (1985) for an econonetric technique that takes into accoint the progressive step function natire of the marginal price of contributions.
} 
TABLE 1

\begin{tabular}{|c|c|c|c|c|c|c|c|}
\hline $\begin{array}{l}\text { ddfugced } \\
\text { Gross } \\
\text { Income*t } \\
\text { Class } \\
\end{array}$ & $\begin{array}{c}\text { Number of } \\
\text { Returns uich } \\
\text { Reported } \\
\text { Contrl- } \\
\text { buclons } \\
\text { (nillions) } \\
\end{array}$ & $\begin{array}{l}\text { Fracelon of } \\
\text { Recurng with } \\
\text { Adfustment }\end{array}$ & $\begin{array}{l}\text { Fraction of } \\
\text { Returns with } \\
\text { Downward } \\
\text { Adjugtment }\end{array}$ & $\begin{array}{c}\text { Total } \\
\text { Reported } \\
\text { Concti- } \\
\text { buctons } \\
\text { (Sbitllon) } \\
\end{array}$ & $\begin{array}{c}\text { Tocal } \\
\text { Auditor- } \\
\text { Adfusced } \\
\text { Concribucions } \\
\text { (Sblilion) } \\
\end{array}$ & $\begin{array}{l}\text { Racio of } \\
\text { Total } \\
\text { Adfustmencs } \\
\text { co Total } \\
\text { Reported } \\
\text { Concriburions } \\
\end{array}$ & $\begin{array}{l}\text { Racio oz } \\
\text { Total } \\
\text { Downward } \\
\text { Adfugctiments } \\
\text { to Tozal } \\
\text { Reporced } \\
\text { Contribuctons }\end{array}$ \\
\hline $\begin{array}{l}\text { Under } \\
10,000\end{array}$ & 1.34 & .24 & .15 & 0.83 & 0.83 & -.004 & נ \\
\hline $\begin{array}{l}10,000- \\
20,000\end{array}$ & 4.93 & .30 & .22 & 3.67 & 3.47 & .053 & .076 \\
\hline $\begin{array}{l}20,000- \\
30,000\end{array}$ & 7.83 & .38 & .29 & 5.93 & 5. :I & .088 & .106 \\
\hline $\begin{array}{l}30,000- \\
40,000\end{array}$ & 6.76 & 93. & .29 & 5.96 & 5.36 & .101 & .117 \\
\hline $\begin{array}{l}40.000- \\
50.000\end{array}$ & 3.83 & .39 & .29 & 4.12 & 3.75 & .090 & .105 \\
\hline $\begin{array}{l}50,000- \\
75,000\end{array}$ & 2.76 & .37 & .28 & 4.19 & 3.90 & .068 & .079 \\
\hline $\begin{array}{l}75,000- \\
100,000\end{array}$ & 0.63 & .33 & .22 & 1.58 & 1.48 & .066 & .067 \\
\hline $\begin{array}{l}100,000- \\
200,000\end{array}$ & 0.54 & .34 & .23 & 2.24 & 2.15 & .041 & .753 \\
\hline $\begin{array}{l}200,000- \\
500,000\end{array}$ & 0.13 & .33 & .22 & 1.50 & I. SS & .342 & $.04:$ \\
\hline $\begin{array}{l}500,000- \\
1,000,000\end{array}$ & 0.017 & .31 & .22 & 0.56 & 0.53 & .058 & .059 \\
\hline $\begin{array}{l}\text { Over } \\
1,000,000\end{array}$ & 0.0073 & $.1 B$ & .13 & 0.67 & 0.66 & .011 & .011 \\
\hline TOTAL & 28.8 & .36 & .27 & 31.2 & 29.0 & .072 & .089 \\
\hline
\end{tabular}

*Figures do not include reported concribuctong of leemizing caxpayers who, upon audic, were deeted not to have enough deduceions to qualify for lcemizacion.

- trecurns as classifed by reporced adjusted gross incone. 
tax rate on the first dollar of charitable contribution. ${ }^{12}$ A standard correction for the tax advantage of giving appreciated assets is taken. 13 The second independent varlable (LNY) is the natural logarithm of adjusted gross income plus IRA contributions winus the taxes that would be due in the absence of charttable contributions. 14 The other three independent variables are dumy variables for the demographic indicators available in the data set: marital status (MAR), the presence of any over-65 exemptions (AGE), and the presence of dependent children (DEP). In order to minimize sample selection bias, the sample is restricted to include only those households who would have itemized deductions even in the absence of any charitable contributions. 15

In the absence of evasion, this equation can be interpreted as a structural equation relating the demand for charitable contributions to characteristics of the taxpayer's environment and preferences. When evasion is considered, a structural equation explaining reported (actual) contributions would include as explanatory variables actual (reported) contributions and noncharity evasion. The first four equatlons estimated in this paper are thus

${ }^{12}$ The marginal federal tax rate is calculated by applying taxable income to the tax table approprlate for the taxpayer's flling status. Thus it does not correctly account for some features of the tax law such as the rinimum tax and income averaglng. Redolng the regression analyses with lnteractive dummy variables for taxpayers subject to these provisions did not reveal any substantive differences from the results reported here.

13 The price variable used is equal to $C(1-t)+(1-C)((1-t)-(0.5 \cdot 0.4 t))$, where $C$ is the proportion of gifts given in cash given by the taxpayer's adjusted gross Income group, $1-t$ is the price of giving cash, 0.5 is the assumed ratio of appreciation to value, an $0.4 t$ is the capital gains tax rate.

14 For comparablitity with earlier studies, I use reported rather than auditorcorrected adjusted gross income both in the calculation of price and in the construction of the income variable.

15 The sample also excludes taxpayers who, upon aud1t, are deemed to have insufficient deductions to qualify for itemization and married taxpayers who file separate returns. 
reduced-form relationshlps. The estimated coefflclent of an independent varlable represents not only the dlrect effect on the dependent varlable but a tso the Indirect effect due to the Induced change in the other endogenous variables.

The results of this estination are presented in the first column of Table 2. The estimated coefficlents on the demographic varlables are of the same sign and of comparable magnitude to those estimated by others. The partlal effects of beling married, having one household member over 65, and of havIng dependent children are all positive and signiflcant. The estimated price elasticity of -2.04 is in the upper range of EIndings of other researchers. The estlmated income elastictty of 0.35 is near the bottor of the range of previous estimates. 16

The second column of Table 2 displays the results of redoing the estmation replacing reported contributions with auditor-adjusted contributions. The estimated coefficients do not change drastically, although there is a statistically signiflcant change in the estimated coefficlents of each of the varlables except DEP. Of principal interest is that the estimated price elasticlty Increases in absolute value from 2.04 to 2.34 , while the estimated Income elastlctiy falls frow 0.35 to 0.27 . This result strongly suggests that the estimated price elastictty of reported contributions is not princlpally an evasion elastictiy. On the contrary, purging the reported statistics of data overstatement increases the estimated price responsiveness of charitable glving.

\footnotetext{
${ }^{16}$ See Clotfelter and Steuerle's Table 1 for a sumary of the earlier EIndings. 17 also experimented with using as a dependent varlable auditor-adjusted contributions, as long as they did not exceed reported contributions. This excludes from consideration upward adjustments of charitable contributions. The results were not significantly different from those reported here.
} 
IABLE 2

Regression Equacions Expiaining Reported and Audicor-Adjusted Contributions

\begin{tabular}{|c|c|c|c|c|c|c|}
\hline $\begin{array}{l}\text { Dependent } \\
\text { Variable }\end{array}$ & $\begin{array}{c}\text { Log of } \\
\text { Reparted } \\
\text { Contribucions }\end{array}$ & $\begin{array}{c}\text { Log of } \\
\text { Auditor-Adjusced } \\
\text { Concributions }\end{array}$ & $\begin{array}{c}\text { Log of } \\
\text { Reported } \\
\text { Concribucions }\end{array}$ & $\begin{array}{c}\text { Log of } \\
\text { Aud } 1 \text { tor-Ad fugted } \\
\text { Contribut fons }\end{array}$ & $\begin{array}{c}\log \text { of } \\
\text { Reported } \\
\text { Concribuctons }\end{array}$ & $\begin{array}{c}\text { Log of } \\
\text { Audicor-Adjusted } \\
\text { Concribut long }\end{array}$ \\
\hline LSP & $\begin{array}{l}-2.04 \\
(0.060)\end{array}$ & $\begin{array}{l}-2.34 \\
(0.063)\end{array}$ & $\begin{array}{l}-1.73 \\
(0.069)\end{array}$ & $\begin{array}{l}-1.96 \\
(0.072)\end{array}$ & $\begin{array}{l}-1.53 \\
(0.133)\end{array}$ & $\begin{array}{l}-1.70 \\
(0.166)\end{array}$ \\
\hline L.YY & $\begin{array}{c}0.35 \\
(0.009)\end{array}$ & $\begin{array}{c}0.27 \\
(0.009)\end{array}$ & $\begin{array}{c}0.36 \\
(0.009)\end{array}$ & $\begin{array}{c}0.28 \\
(0.009)\end{array}$ & $\begin{array}{c}0.34 \\
(0.017)\end{array}$ & $\begin{array}{c}0.26 \\
(0.021)\end{array}$ \\
\hline MAR & $\begin{array}{c}0.64 \\
(0.029)\end{array}$ & $\begin{array}{c}0.72 \\
(0.030)\end{array}$ & $\begin{array}{c}0.57 \\
(0.029)\end{array}$ & $\begin{array}{l}0.65 \\
(0.031)\end{array}$ & $\begin{array}{c}0.53 \\
(0.056)\end{array}$ & $\begin{array}{c}0.59 \\
(0.070)\end{array}$ \\
\hline AGE & $\begin{array}{c}0.45 \\
(0.034)\end{array}$ & $(0.034)$ & $\begin{array}{c}0.47 \\
(0.034)\end{array}$ & $\begin{array}{c}0.56 \\
(0.036)\end{array}$ & $\begin{array}{c}0.50 \\
(0.064)\end{array}$ & $\begin{array}{c}0.60 \\
(0.081)\end{array}$ \\
\hline DEP & $\begin{array}{c}0.13 \\
(0.023)\end{array}$ & $\begin{array}{c}0.14 \\
(0.023)\end{array}$ & $\begin{array}{c}0.12 \\
(0.023)\end{array}$ & $\begin{array}{l}0.13 \\
(0.023)\end{array}$ & $\begin{array}{c}0.16 \\
(0.043)\end{array}$ & $\begin{array}{c}0.18 \\
(0.054)\end{array}$ \\
\hline PROB & & & $\begin{array}{c}4.96 \\
(0.54)\end{array}$ & $\begin{array}{c}5.97 \\
(0.56)\end{array}$ & $\begin{array}{c}4.58 \\
(1.02)\end{array}$ & $\begin{array}{l}6.46 \\
(1.28)\end{array}$ \\
\hline PCOST & ! & & & & $\begin{array}{c}0.07 i \\
(0.008)\end{array}$ & $\begin{array}{l}0.094 \\
(0.010)\end{array}$ \\
\hline Constant & $\begin{array}{c}1.14 \\
(0.07 ;)\end{array}$ & $\begin{array}{c}1.62 \\
(0.080)\end{array}$ & $\begin{array}{c}0.98 \\
(0.079)\end{array}$ & $\begin{array}{c}1.42 \\
(0.082)\end{array}$ & $\begin{array}{c}1.12 \\
(0.150)\end{array}$ & $\begin{array}{c}1.61 \\
(0.188)\end{array}$ \\
\hline $\begin{array}{l}\text { No. of } \\
\text { Observations }\end{array}$ & 23894 & 23894 & 23894 & 23894 & 23894 & 23894 \\
\hline $\begin{array}{l}\text { Standard } \\
\text { error of } \\
\text { estimate }\end{array}$ & 1.53 & 1.60 & 1.53 & 1.59 & 1.52 & 1.58 \\
\hline $\mathrm{R}^{2}$ & 0.307 & 0.276 & 0.309 & 0.280 & 0.318 & 0.293 \\
\hline
\end{tabular}

SOTE: Standard errors are in parentheses.

*yeasured in chousands of dollarg. 
I rext investigate expanding the set of Independent variables to Inclide proxies for the additional influences on charitable contributions and thelr overstatement suggested by the first-order conditions of the individual's maximization problem. One such factor identifled was the probability of detection of evasion.

The probability that a given tax return will be subjected to audit 18 clearly is not constant and depends on certain characterictics of the return. The IRS develops formulas for identifying particularly likely candidates for audit; the TCMP survey is ane input into developing these formulas. For obvious reasons, the formulas themselves are a secret closely guarded by the IRS. However, it is public information how the fraction of returns audited differs for different subgroups, called exarination classes, of the taxpaying population.

The results of including as an explanatory varlable the appropriate fraction of returns audited in the taxpayer's exanination class (PROB) are presented in the third and fourth columns of Table 2 . $^{19}$ The estimated coefficient on PROB is positive and significant for both reported contributions and auditor-adjusted contributions, although the estimate is significantly higher E or auditor-adjusted contributions, 5.97 compared to 4.96. This implies that

${ }^{18}$ This refers to a standard audit, not a TCMP audit, for which the selection procedure is different.

${ }^{19}$ Note that the amount of reported charitable contributions cannot affect which examination class a return is placed in, which depends on the sum of the positive elements of income, the presence of self-employment income, and the presence of farm income. One's examination class does, though, depend on the taxpayer's report of other components of income, and therefore PROB may depend on the extent of non-charity evasion. If the disturbance term in the non-chartty evasion equation is correlated with the disturbance term In a charity equation, then $P R O B$ and the latter disturbance term will be correlated, so that the oLS estimator will be inconsistent. 
a higher value of $p$ tends to decrease charity overstatement, as the theory would suggest. 20

According to the behavioral model of Section 3, another influence on charitable contributions and their overstatement is the utility cost of detection, which depends on the total amount of evasion attempted, the pecuniary penalty likely to be charged, and any psychic costs to being audited. To the extent that psychic costs can be proxied by demographic variables such as age, they are already accounted for in the vector of independent varlables. The expected penalty to be charged for any given amount of evasion probably does not vary systematically by individual. The data does, though, contain a proxy for the dollar cost of detected non-charity evasion-the auditor's suggested change in the taxpayer's total tax liabllity, net of the change due to any adjustiment in charitable contributions. Because non-charity evasion is endogenous, it is an inappropriate right-hand side variable.

Colums 5 and 6 of Table 2 report the results of an instrumental-variables estimation procedure. The instruments for the dollar cost of detected noncharity evasion are dumy variables for the presence of total income, rental income, Schedule $C$ income, and capital gains incore. These are presured to influence the opportunities for non-charity evasion, but not the attractiveness of charity overstatement. Including the predicted value of the dollar cost of

20 To a first approximation, estimated charity overstatement will increase with an explanatory variable if $\left(\frac{C_{R}}{C_{A}} \hat{B}_{R}-\hat{B}_{A}\right.$ is positive, where $\hat{B}_{R}$ and $\hat{B}_{A}$ are the estimated responses to the variable of reported and auditor-adjusted contributions, respectively. Because $\left(\frac{C_{R}}{C_{A}}\right)$ is approxinately 1.07 in the aggregate, $\left(\frac{C_{R}}{C_{A}}\right)_{R}-\hat{B}_{A}$ is negative for $P R O B$, suggesting that overstatement declines with a higher probability of detection. 
detected non-charity evasion (PCOST) does not substantially affect the estimated coefficlents of the other variables. It does slightly reduce the estimated price responsiveness of reported and actual contributions. As the theory suggests, a higher value of PCOST reduces the amount of charity overstaterent. Both reported and auditor-adjusted contributions increase with PCOST, but the increase in reported contributions falls short of the increase in auditoradjusted contributions.

Finally, the dependence of the probability of detection on the amount of charitable contribution overstatement is likely to affect taxpayer behavior. Unfortunately, no appropriate proxy for this is avallable. If this is proportional to the probability of detection itself, then the PROB variable is already picking up the effect of this variable on behavior.

The procedures reported in Table 2 were repeated separately for cash and non-cash contributions. The results for cash contributions, which accounted for $87 \%$ of the value of all contributions by itemizers in 1982 , are quite similar to the aggregated results--price elasticities in excess of two, which rise slightly when reported contributions are replaced by auditor-adjusted contributions. For non-cash contributions, the estimated price elasticity is appromixately minus one and the estimated income elasticity is approximately 0.1. Neither of these estimated coefficients changes auch when auditoradjugted contributions are substituted for reported contributions.

\section{Conclissions}

These preliminary results suggest that the answer to the question posed in the title--are estimated tax elasticities really just tax evasion elasticitles?--1s no in the case of charitable contributions. The tax responsiveness of charitable giving that has been detected using tax return data cannot be 


$$
-17-
$$

ascrlbed to the tax responsiveness of overstating actual giving. In Eact, overstatement is apparently less price responsive than actual giving, lmplying that the responslveness of actual giving is higher than is suggested by studying reported contributions.

Estimates of all types of behavioral response, based on tax reports, Inevitably reflect both an evasion elasticlty and an underlying behavioral elasticlty. Poterba (1987), using aggregate time-serles data on reported capital galns realizations and compliance rates, concludes that at least onequarter of the observed capital gala reallzation response to changes in marginal tax rates is due to changes in reporting behavior, rather than portfollo behavior. Thus, the answer to the question posed in the title of this paper may be "to some extent, yes" for activitles other that charltable glving. This is a subject worth pursuln: ecause the pollcy implications of observed responsiveness to taxation depend on how much of this response is in the reporting of behavior rather than the behavior itself. 
Alexander, C. and Feinstein, J., "A Microeconometric Analysis of Individual Income Tax Evaston Behavior," mimeo, M.I.T. (August 1986).

Allingham, 4. G. and Sandro, A., "Incore Tax Evasion: A Theoretical Analysis." Journal of Public Economics 1 (1972): 323-338.

Clotfelter, C., "Tax Evasion and Tax Rates: An Analysis of Individual Returns." Review of Economics and Statistics 45 (1983): 363-373.

Clotfelter, C. and Steuerle, C. E., "Charttable Contributions." In H. Aaron and J. Pechman, eds., How Taxes Affect Economic Behavior. Washington, D.C.: The Brookings Institution, 1981 .

Dibin, Jeffrey A. and Wilde, Louls L., "An Empirical Analysis of Federal Income Tax Auditing and Compliance." California Institute of Technology Soclal Sclence Working Paper 615. October 1986.

Internal Revenue Service, Taxpayer Compliance Measurement Program Handbook, January 1984.

Pitt, M., "Smuggling and Price Disparity." Journal of International Economics 11 (1981): 447-458.

Poterba, J., "Tax Evasion and Capital Gains Taxation," American Economic Review 77 (1987).

Reece, W. and Zieschang, K., "Consistent Estimation of the Impact of Tax Deductibility on the Level of Charitable Contributions," Econometrica 53 (1985): $\quad 271-293$.

Witte, A. and Woodward S., "The Effect of Tax Laws and Tax Administration on Tax Corpliance: The Case of the U.S. Individual Income Tax," Nat Ional Tax Journal 38 (March 1985): 1-14.

Yitzhak1, S., "A Note on 'Income Tax Evasion: A Theoretical Analysis'." Journal of Public Economics 3 (1974): 201-202. 